\title{
砂浜海岸における島式漁港の計画事例(沓尾漁港・道川漁港) \\ Development Programs of Offshore Fishing Port in Sandy Beach
}

\author{
長野 章: • 佐藤信- - $^{* *}$.川瀬 将 ${ }^{*}$ \\ Akira.Nagano, Sinichi.Sato, Susumu. Kawase
}

\begin{abstract}
The objective of this study is lay the island type offshore fishing ports plan. This deve1opment plans of fishing ports (Kutuo fishing port and Mitikawa fishing por $t$ ) which is adaptable to drift sand, is able to accommodate fishing boats safety, and causes least effects against topographic change.

Keywords: Offshore Fishing Ports, Drift Sand, Topographic Change, In-Port Calmness
\end{abstract}

1.はじめに

島式漁港は国桻漁港(北海道長万部町)において港内埋没の影謷と漁港建設による周辺海浜への影䇾を最小限に するため計画され、現在建設が進められている。国縫漁港は内湾に位置し比較的静穞な水域にある。本調査は、

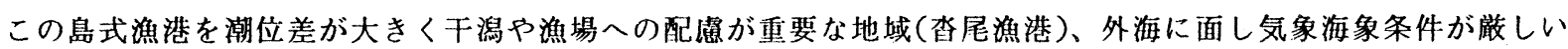
地域(道川漁港)に適用するため、利用上の問題点と水産業振興・地域振興の課題の検討や、現地観測調査に基つ く静穏度と海浜变形解析を実施したもので、砂浜海岸の高度利用を図るとともに漂砂対策として有効で周辺海浜 への影溉の少ない島式漁港の調査計画を行ったものである。

2 . 調査の目的

200 海里体制の定着とともに、わが国の周辺海域を高度に利用することが水産業振興の面から大きな課題と なってきている。そのため、增養殖技術の研究開発、㴔場の整備等が皘極的に進められており、また、それに対 応した漁港の整備が図られている。こうした中で、わが国の海岸線延長の約 3 分の1を占める砂浜域は、漁場と しての有効な利用が遅れており、また良好な漁場に近接していても、生産基地となる漁港を整備するにあたって 漂砂による航路および港内の埋没が大きな問題となるなど、高度利用を四るうえで解決すべき課題が多い。また、 余啹の增大にともなうレクリェーション需要の高まりは時代の䞶勢であり、水産振興のみならず観光レク振興の 視点をも包含して砂浜域の開発・整備・保全を行っていく必要がある。さらに漁港は水産業の基地であるととも に、漁村地域の生活の核としての役割も持ち、背後の漁村と一体となった地域の活力の場として整備することが 重要である。

本調査は砂浜海岸に設置される2つの漁港（杳尾漁港・道川漁港）について利用上の問題点と水産業振興・地 域振興の課題を検討し、漁業生産活動の向上のみでなく環境保全や增養殖漁業の振興等を考慮した漁港整借計画 を作成することを目的とする。

3. 漁港の概要

（1）沓尾漁港

沓尾漁港と長井漁港は九州北部の福岡県行橋市にあり、波稳やかな周防潍に面している。いつれの地区も小型 底引網、小型定置網、採貝、のり養殖等の沿岸鮘業が営まれている。沓尾漁港は椷（はらい）川の河口に位置し ており、1.6 km離れた長井漁港とともに遠线（汀線付近の海底勾配 1/300）の干潟海岸にある。沓尾漁港は泼川 からの流出土砂で泊地内が埋没し、干满差が $4 \mathrm{~m}$ と大きいために干潮時には使用出来ない状況である。長井漁港 は漁港施設の整储がほとんど行われていない。このため漁業者は近隣の刘田港を利用して漁獲物の荷揚げをおこ なっているが、岸壁天端高が高く小型漁船が利用しにくい、荷挪施設がない、長時間の通勤を強いられること、 潮の干満を見て不定期な出漁をしているなど漁業活動および水産業の振興のための制約が多い。また行橋市は北 九州市の $20 \mathrm{~km}$ 圈内にあり急激な人口增加が見られるや貫重な干潟䟱境の保護から県立公園に指定され、市民のた めの魅力的な環境の整借が急がれている。このため水産業振興と地域振興を目的として、新たな漁港の整備が始 められている。

（2）道川漁港

道川漁港のある秋田県岩城町は、秋田県南西部に位置し、総面積は $107.98 \mathrm{~km}^{2}$ (東西 $8 \mathrm{~km}$, 南北 $16 \mathrm{~km}$ ) で、地形 は三方を出羽山地に囲まれ、西側は日本海に面した長い海岸線を有している。冬季の気候は厳しく降雪が多い。 前面沿岸海域は漁場としても比較的恵まれた地域で、小型定置網、刺網の他、たこ漁業、一本釣、わかめ養殖等 * 正会員 (財)漁港漁村建設技術研究所（107 東京都港区赤坂 6-13-16）

**（財)漁港漁村建設技術研究所 
が行われているが、これまで漁港が整備されてこなかったために冬期の出漁が限定されることや漁港施設用地が ないこと、漁船の揚げ下ろしに多大な労力を要する等の問題があり、漁業活動に大きな制約を受けていたが、昭 和 61 年に道川漁港（第 1 種漁港）の指定を受け、第 8 次漁港整備長期計画から漁港の整備が始められている。 また、漁港計画地周辺は遠线の砂浜が続いているが、これまでは、漁業以外の利用は、その一部が夏季の海水浴 や花火大会等に利用されているのみであり、今後の開発が期待されている。

\section{4. 調査の内容}

漁港整借のための調査として次の項目を実施した。

(1)漁港および周辺地域の現況と漁港整䚛課題の検討

(3)必要施設と規模の検討

(2)漁港整借基本方針の検討

（1）沓尾漁港整借計画調査

調査は図 -1 の調査フローに基ういて実施した。 漁港整備の計画を立案する場合、漁獲量、漁船 数や漁業形態等について現況を調査し、水産振興 の方向と将来予測により、規模の算定や施設整備 の計画が行われる。また、漁港基本施設の配置計 画については、波浪などの気象・海象条件と水深 や漂砂動向等の海岸特性を知ることが必要である。

漁業の現状、漁港利用の問題点や海洋レクにつ いて既往資料と現地踏査により調査し、整備基本 方針を検討した。併せて海岸特性や漂砂特性の把 握を行い、島式漁港の整備計画を提案した。提案 した計画案について港内静稳度解析と漂砂解析（ 汀線変化予測および 3 次元海浜变形シミュレーシ ヨン）を実施して漁港配置計画案を作成した。

（2）道川漁港整備計画調査

調查は、困 -2 の調査フローに基づいて実施し

(1)波浪、流況、地盤等の現地観测調查

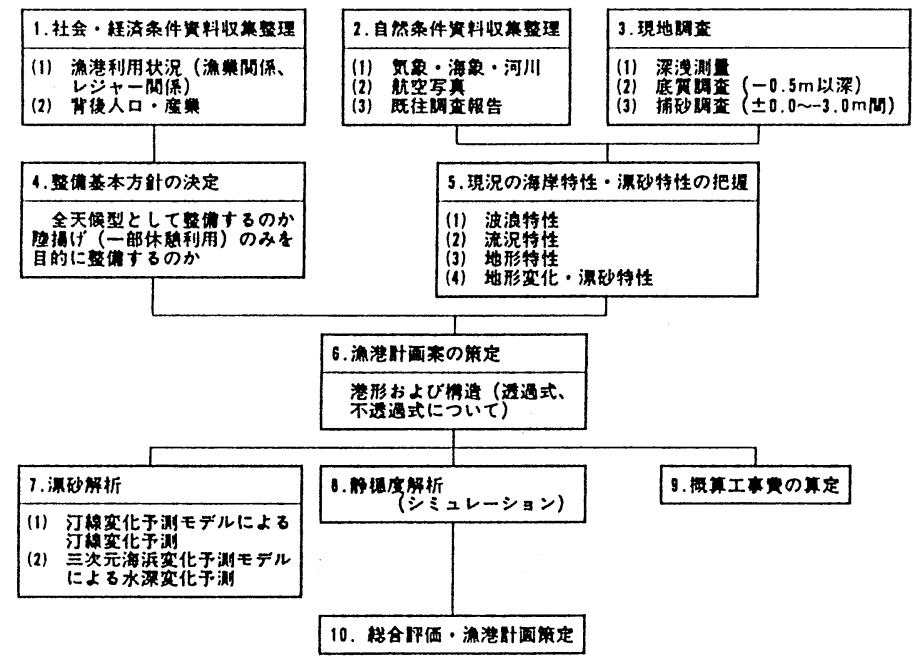

図一１沓尾漁港整供計画調査フロー た。
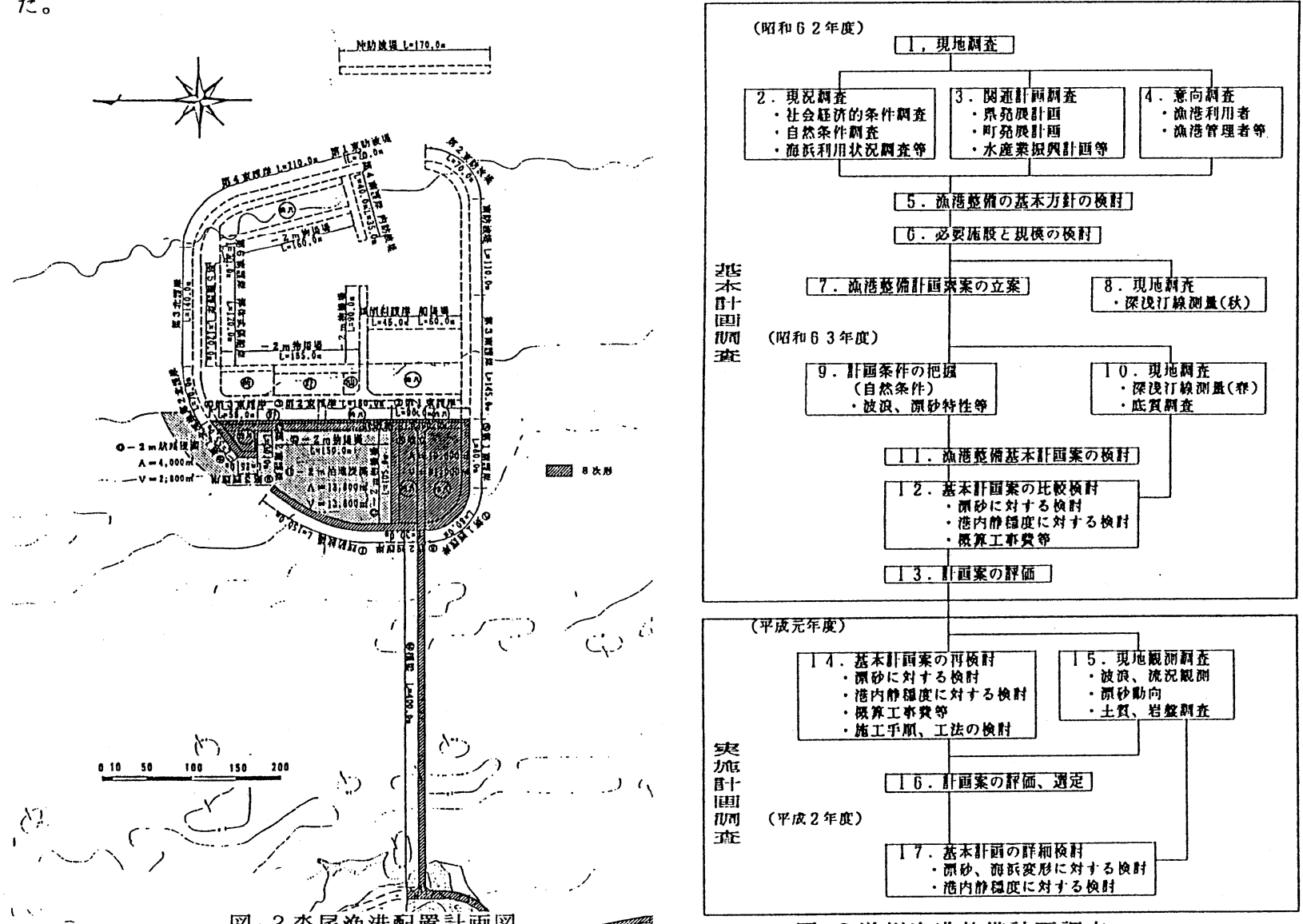

図-3 沓尾漁港配置計画図

四-2 道川漁港整備計画調査フロー 
基本計画調査として、漁港整備に係わる現状、漁業者の漁港整備意向、漁港計画地沿岸の深浅測量等の調査を 行い、漁港整備の課題を把握するとともに、既存の資料を基に、当地域の波浪、漂砂等の海岸特性を把握し、漂 砂に対する検討、港内静穞度に対する娭郡を踏まえて、島式漁港整借基本計画案を提案した。

実施計画調査は、漁港の配置計画に関して、最も配虑が必要な問題を静穞度と漂砂および漁港建設による周辺 海浜への影翼と考元、漂砂を中心とする海域条件を現地調查により把握し、漂砂に対応し、なお安全に㴔船を俰 留でき、海浜变形に対する影製が少ない漁港整储計画案の検討を行った。

1) 現地調査

(1)波浪調查 (2)流況調査 (3)漂砂調查 (4)深线汀線测量 (5)土質調査・岩盤探査

2）漁港整借計画および施工手順検討

利便性、波浪、漂砂等を考慮して、漁港の位置および漁港外郭施設の配置検討を行い、海浜变形予測シミュレ ーション解析（1-1 i n e モデル）による周辺海浜への影謷評洒を行った。

3）現地調査結果による検証

現地漂砂動向調查結果をもとに、三次元数值シミュレーション解析により、漂砂による航路㧍よび港内堆砂、 周辺海浜への影整評洒を行い、港口の向きと外郭施設の配置等についてさらに梌討を行った。

5 . 沓尾漁港整借計画の提案

（1）查尾漁港整備の基本方針

漁港整備計画の立案には、漁港整備に係わる現状や漁業者の漁港整備意向を把暒することが必要であると共に、 漁港整備を含めた砂浜域の開発にあたって、開発が自然破壊につながらない上うな配廂が求められる。

沓尾漁港における現状と整備課題を検討し、潐港整備の基本方針を次のようにした。

(1)漁業の振興と漁業者の生活の改善を困る。

(2)活魚流通の進展が可能となり、流通面での改善効果が期待できる計画とする。

(3)自然と調和した美しく、特鹳りある漁港形態を創案する。

(4)鮇業と調和した海洋レクの振興が可能となるような計画とする。

(5)早期供用開始が可能となるような計画とする。

（6漂砂対策を考慮した漁港整備計画とする。

この基本方針より島式漁港が提案されたが、主な理由は次のものである。

(1)港内埋没防止の配慮を行った場合、島式漁港としたほうが経済的で、漁港の早期供用が可能である。

(2)干渴の埋立面皘が小さい分、㴔場消失面積が少なくできる。また海岸地形の变化を小さくでき、磯根資源や 增養殖場の保全、海水浴や潮干狩り施設の保全が図れる。

(3)島式漁港が観光に利用され地域の活性化に役立つ。

(2) 海岸特性、漂砂特性

(1)風観测データから $10 \mathrm{~m} / \mathrm{s}$ 以上の强風は、 S E ，E S E および E 方向で多く発生する。波浪データからは 0 . $6 \mathrm{~m}$ 以下が全体の $90 \%$ を占める。激浪時の最大は E S E 方向で波高 $4.6 \mathrm{~m}$ 、周期 7.9 秒である。

(2)底質粒径は概扣 $0.1 \mathrm{~m} \mathrm{~m} \sim 0.4 \mathrm{~mm}$ の範囲で、平均粒径は $0.25 \mathrm{~mm}$ である。この粒径で波による移

動限界水深は、 $2.5 \mathrm{~m} \sim 3.0 \mathrm{~m}$ 以深と考元られる。

(3)海底地形は-1 mより线いところでバー・トラフが形成され、河口側で多い。

(4)航空写真からは河口前面で河川からの流出土砂の堆積が見られるが、明確な沿岸漂砂の卓越方向は見られな い。

(5)浮遊砂の調査からは $-3 \mathrm{~m}$ 以深では砂の巻き上げや漂砂移動はないと考元られる。

（3）漁港配㯰計画

港内静瑷度の確保と漁船の安全係留ができること、漂砂による埋没の影豐がないこと、周辺海岸特に海水浴場 や貝の漁場に対する影隌が小さいことを考慮して、図-3に示す漁港配置を提案した。特徽を以下に示す。

(1)砂の移動限界水深である- $3 \mathrm{~m}$ 以深に港口部を設置した。

(2)計画位置は、海水浴場への地形変化の影隌が小さく、祐川河口部に波浪による土砂の堆皘で河口閉塞を生じ ないように戨川と長井海岸中間位置とした。ここは半島の前面で橋梁が短く、㚛尾と長井の両集落の中間位 置である。

(3)係留岸壁の配置について、風に対する配慮をした。

（4）港内静穞度シミュレーション

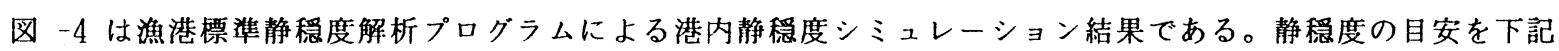
に示すが、四からも明らかなように、(a)激浪時、(b)通常荒天時とも必要な静稳度が確保される。 


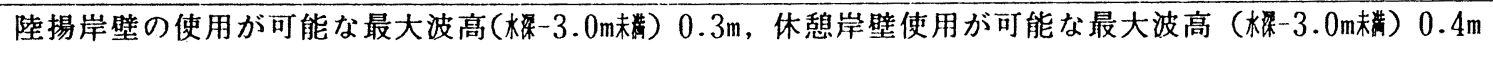
航路が使用可能な最大波高（櫂-3.0m以上） $1.2 \mathrm{~m}$

(5) 漂砂解析

(1)長井海水浴場の汀線変化

長井海水浴場は、漁港計画位置の右側の海岸部にある。汀線变化予测シミュレーションを使って漁港が建設 された10年後に予想される汀線の形状を図 -5 に示した。計算結果では、漁港背後で海岸線が前進し、その両

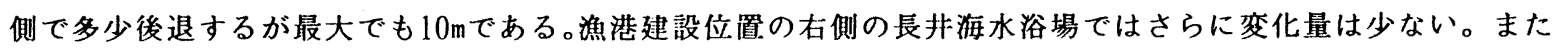
鿆川前面への堆積もなく、河口閉塞の憗念はないものと推定される。

(2)漁港周辺の地形変化予测

漁港周辺の地形变化予測は、三次元海浜变形シミュレーションを用いた（図-6）。

岸側の漁港背後周辺および漁港の両側に堆砂傾向がみられるが、港口部付近の変化は少なく、岸側の-2m泊地 および航路では堆砂㑯向はみられない。

（a）激浪時の波高
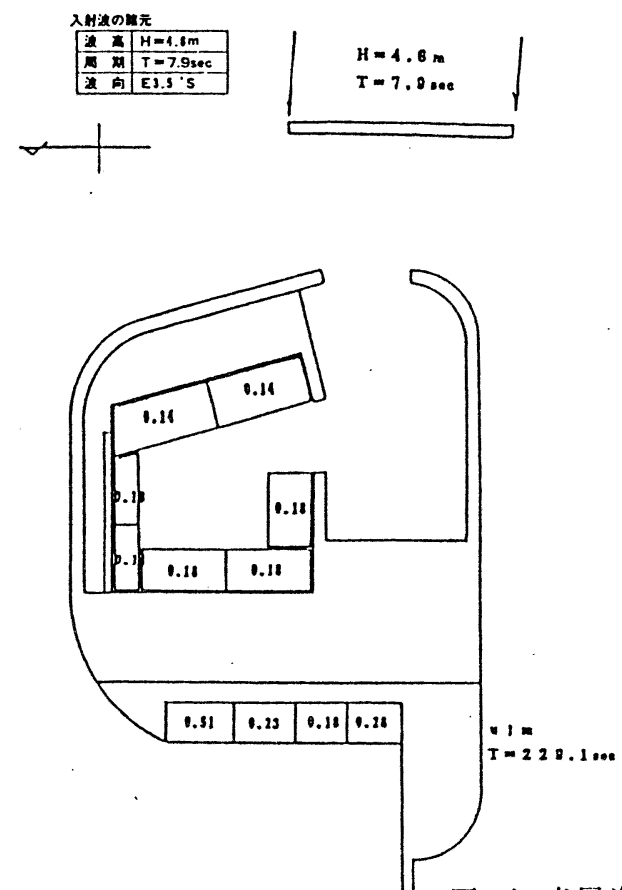

図-4 昲尾漁港港内静稻度計算結果 （b）通常の荒天時の波高
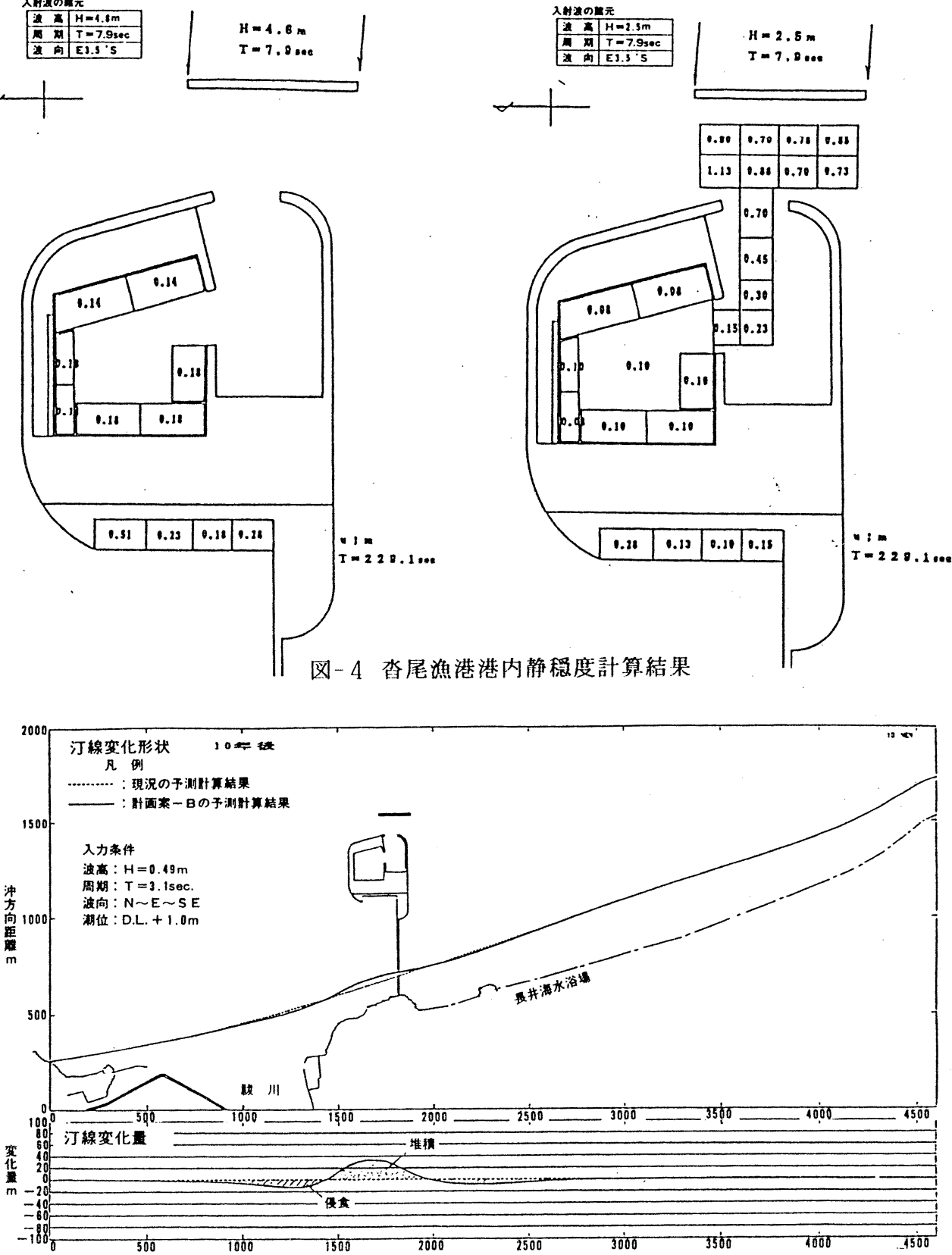

図-5沓尾漁港汀線変化予测シミュレーション結果 
6. 道川漁港整備の提案

（1）道川漁港整備の基本方針

基本計画調査により、漁港整備課題を整理し、漁港

整借にあたっての基本方針を以下のようにした。

(1)漁船等の安全性、漁業活動の円滑化を図るための 基本的施設を整備する。

(2)增養殖漁業の振興や活魚流通の扗大に対応した施 設を整備する。

(3)水産物の観光活用や観光レク振興に対応する施設 を整備する。

(4)漂砂対策を十分に考慮し港内埋没と周辺海浜への

影響を極力少なくするような施設配置を計画する。

(5)周辺環境と調和し、沿岸域の高度利用を可能とす る施設を整備する。

このうち、(4)の漂砂対策等の配慮は、外郭施設の配 置を行うためには基本的な項目であり、静稳度と併せ て十分な検討が必要である。漁港計画地泀岸の調査や 既往資料の解析より、当地域の海岸特性をまとめると 以下のとおりである。

(1)当海域に来襲する波浪は、平均波高で冬期に約 $2 \mathrm{~m}$ 、夏期に約 $0.5 \mathrm{~m}$ で日本海特有の冬期高波高、夏期静穏 の傾向が明瞭であり、漂砂移動は特にこの冬期波浪に よると推定される。

(2)当地区は、バー型海浜形状を示し、特に水深 $2 \mathrm{~m} \sim$ $6 \mathrm{~m}$ 付近に形成されたバー・トラフの規模が大きく、岸

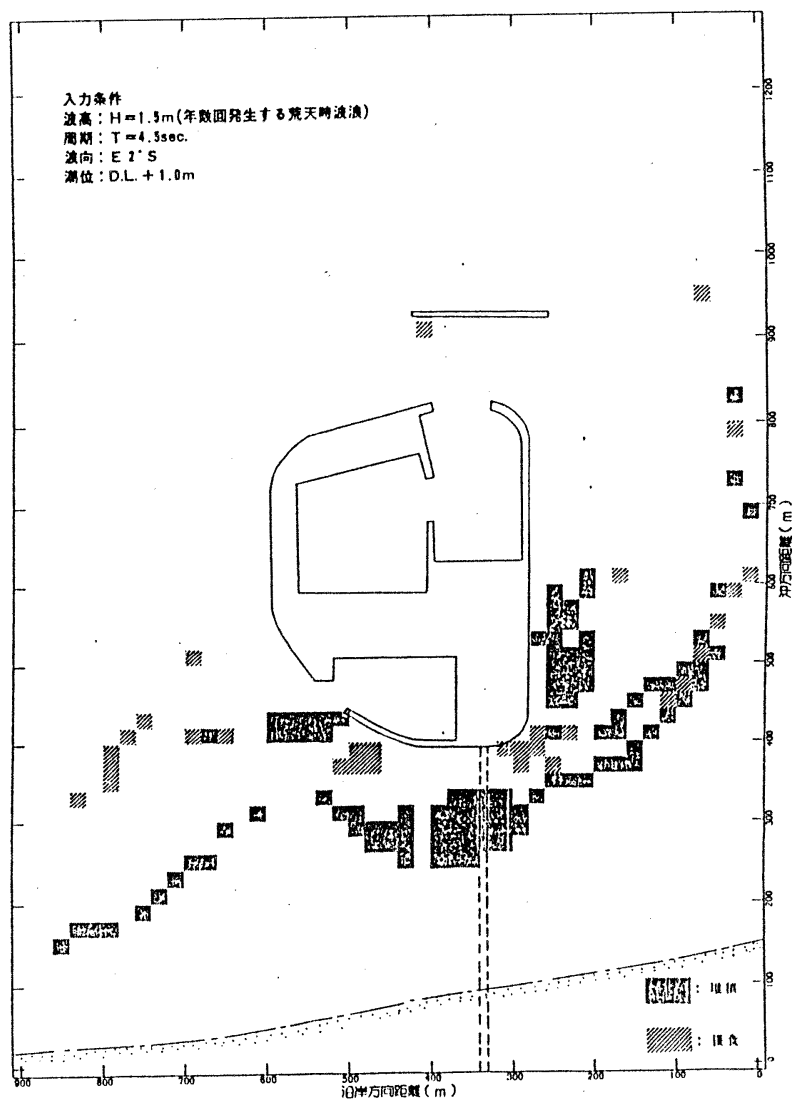

因-6 沓尾潐港周辺の地形変化予测結果 沖漂砂の著しい海浜であるといえる。沿岸漂砂の向きは、季節により違いがあり、概抣いながらも北向き に卓越している。

(3)海底勾配は水深 $6 \mathrm{~m}$ 以浅で約 $1 / 80$ 、それ以深で約 $1 / 170$ の遠浅のバ一型海浜であり、水深 $6 \mathrm{~m}$ 以浅 で岸沖漂砂の著しく、水深 $6 \mathrm{~m}$ 以深での地形変化は少ない。

(4)海底の底質は、中央粒径で $0.15 \sim 0.3 \mathrm{~m} \mathrm{~m}$ の範囲にあり、水深 $6 \mathrm{~m}$ 以牫ではバラッキがあるが、水深 $6 \mathrm{~m}$ 以深では細粒化しほとんど同一粒径 $(0.16 \mathrm{~m} \mathrm{~m})$ となっている。

（2）島式漁港の提案

地形的な制約のない、あるいは地形を遮蔽物として利用できない場所に漁港を整備する場合、突堤式の漁港と して、防波是で海面を囲って、静穏な水域を確保し、陸から連続して漁港施設用地、係船岸等を設けるのが最も 一般的である。この形式は、陸から連綩しているために利用しやすく、また比較的水深の浅い所に構造物を配固 できるため経済的である等の利点がある。

しかし、この配置形式を道川漁港に適用した場合、港口部が水深 $6 \mathrm{~m}$ 以深となるように外郭施設を延ばさない と港内堆砂を生じることが、近隣の既設漁港の状況や先に示した当地区の海岸特性から、容易に予想できる。ま た、長く続いた海岸線を漁港施設により分断することになるとともに、沖に延びた外郭施設が沿岸流を阻害する ため、漁港の周用は上手侧で堆積、下手側で侵食といった著しい地形変化を誘発することになる。

漁港整備のみを考えた場合は、港内の維持浚渫を定期的に行ったり、外郭施設を沖に延ばして周辺海岸の变形 に対しては離岸堤の設置や機械的な除砂（たとえばサンドバイパス）を行うといった漂砂対策も、あるいは可能 であるが、砂浜海岸の高度利用を図る上では問題が多いと思われる。

島式漁港は、砂の移動の少ない沖に人工島形式で漁港を整䚛し、陸との間を橋梁で結ぶものであり、港内堆砂 や周辺海岸の变形を極力おさえるためには最も効果的であると考えられる。図一7に模式的に示すように、漁港背 後の連絡橋基部で堆砂が生じるが、その規模は大きなものではなく、むしろ海水浴や潮干狩など海レクの場とし て利用できるものと思われる。また、漁港港口部は矺波带より沖に配置されるため、堆砂の影稫は、漁港にまで 及ぶことはなく、漁港内が埋没する恐れは少ないと言える。

さらに、漁船の係留には静稳な水域の確保が重要であるが、それと同時に風に対する配慮も必要であるため、本 案では息の沖側外周部に防風堤を設け、海風乞越波洔の飛沐を極力防ぐよう配慮した。島の背後の静稳水域は、 苗養水面やマリンスポーツの場として活用することが可能になるとともに、陸域を一体的に整些することによっ 
てここを訪れる人ィが「海を楽しむ」こしのできる埸が創出されるし思われる。

(3) 外郭施設配置案の検討

基本計画調査では、島式漁港の配置計画として 3 案を対象に漂砂と静穞度について概略検討を行った。

(1)漂砂に対する検討

既往資料および海岸特性をもとに港内堆砂の定性的検討を行った。また、周辺海浜への影隌を 1 -1 i n e モデル（汀線变化予測モデル）を用いて、5 年後の予测汀線变化を計算し、比較検討を行った。

(2)静稳度の検討

高山（1981）の方法により、港内の静穏度の計算を行った。
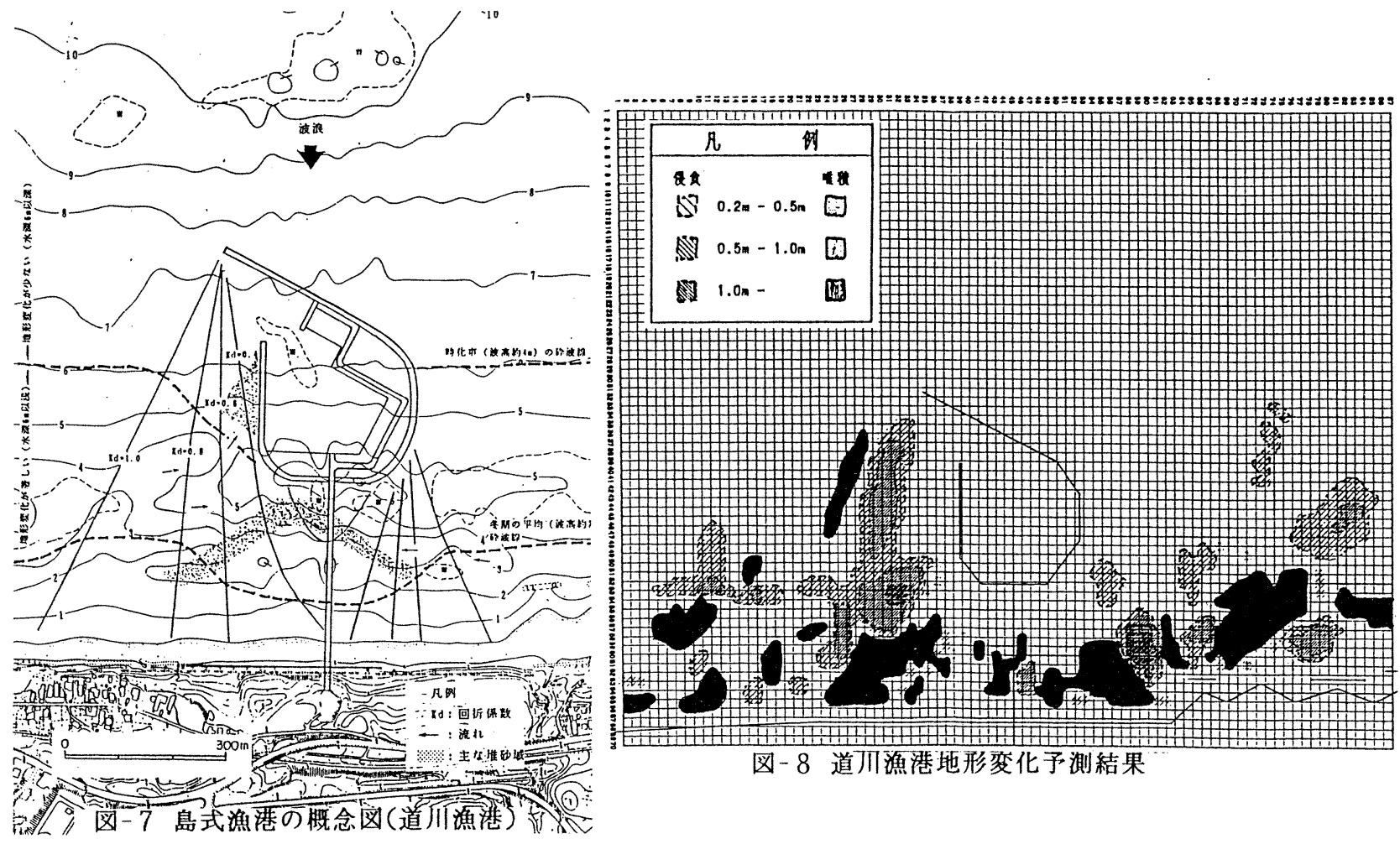

図-8 道川漁港地形変化予測結果

(4) 実施計画調查

実施計画調査では、基本計画資料や現地篗測にもとつく海域特性を参考として、配置計画（6 案）を対象に、 基本計画と同様の手法により検郡を行った。最終的に提案した港型に対し 3 次元海浜変形シミュレーションを実 施した結果を図-8に示す。漁港背後には堆砂域が生じるが港口部における港内埋没の恐れは少ないといえる。

7.まとめ

漁業生産の向上、環境の保全や海洋レクなどの総合的な利用を目的とした漁港整備計画の立案を福岡県の沓尾 漁港と秋田県の道川漁港について実施した。2つの漁港は波浪条件や底質が異なるものの同様な手法を用いて調 査が行われている。本調査で提案した島式漁港は、砂浜海岸の高度利用を困ると共に、漂砂対策として有効であ り、周辺海浜への影響も少なく、環境保全の面からも有効な方法といえる。

参考文献

1）昭和63年度沓尾漁港修築工事に伴う基本計画調査報告書(財団法人 漁港漁村建設技術研究所 平成元年3月)

2）平成元年度道川漁港修築・測量及び調查業務委託報告書(財団法人 漁港漁村建設技術研究所 平成2年3月) 